Г.Б. Варламов, док. тех. наук, проф., ORCID 0000-0002-4818-2603

K.О. Романова, канд. тех. наук, ст. вик., ORCID 0000-0001-9738-3383

M.C. Мухін, магістр, ORCID 0000-0002-8961-6543

Національний технічний університет України «Київський політехнічний інститут імені Ігоря Сікорського»

\title{
АЕРОДИНАМІЧНІ ТА ТЕПЛОВІ ПЕРЕВАГИ РОБОТИ КАМЕР ЗГОРАННЯ ГАЗОВИХ ТУРБІН ПРИ ЗАСТОСУВАННІ МІКРОФАКЕЛЬНОЇ ТЕХНОЛОГІЇ ГАЗОСПАЛЮВАННЯ
}

3 використанням 3-Д моделювання досліджено аеродинамічні, сумішоутворювальні та теплові особливості організації прочесу спалювання у камері згорання газотурбінної установки газоперекачувального агрегату типу ГТК-10 зі штатними пальниками. На основі аналізу комплексу характеристик обтрунтовано необхідність, розроблено та впроваджено нову конструкиію пальникової системи для ГТК-10 на основі нової мікрофакельної технологї газоспалювання, доведено переваги застосування МТС-пальників для інтенсифікації процесів сумішоутворення та спалювання палива у камері згорання із досягненням високого рівня енергоефективності та екологічної чистоти енергоперетворень.

Ключові слова: аеродинаміка, газова турбіна, камера згорання, спалювання газу, мікрофакельна технологія, енерго-екологічна ефективність

Вступ

Прагнення України інтегруватися у Європейський Союз (СС) мотивує підприємства здійснити певні кроки щодо покращення екологічних показників енреговиробництва, оскільки цього вимагають законодавчі документи ЄС. Під впливом введення нормативно-правових документів відповідно до Директив СС [1,2] перед підприємствами, що використовують в енергетичних установках органічне паливо, стоїть завдання покращення якості роботи теплоенергетичного обладнання із забезпеченням високих показників енергетичної ефективності і екологічної чистоти під час його експлуатації. Відповідно до Закону України «Про Основні засади (стратегію) державної екологічної політики України на період до 2030 року» [3] стає пріоритетним питання захисту довкілля, запровадження екологічно безпечних, ресурсо- та енергозберігаючих технологій.

Досягнення необхідних показників експлуатації енергетичного обладнання за вимогами Директив СС та Закону України можливо двома шляхами: перший шлях-проведення реконструкції джерел енерговиробництва чи заміна застарілого устаткування на нове, більш енергоефективне; другий шляхздійснення модернізації паливоспалювального обладнання, яке є основним джерелом екологічного забруднення довкілля та надмірних питомих витрат органічного палива (природного газу).

Перший шлях має певні переваги перед другим, а саме: можливість реалізації комплексних якісних змін в умовах експлуатації обладнання з впровадженням комплексної автоматизації усіх аеродинамічних та теплоенергетичних процесів, покращення енергетичних, екологічних та економічних показників діяльності підприємства 3 одночасним підвищенням безпечних та санітарно-гігієнічних умов роботи персоналу. Недоліком цього шляху є висока вартість капіталовкладень, довгий термін його реалізації від початку проектування, узгодження проекту, закупівлю обладнання, монтажу, пуско-налагоджувальних робіт і здачі в експлуатацію усього обладнання у комплексі та значний термін окупності, який може перевищувати традиційний показник для енергетики у 12 років.

Перевагою другого шляху $є$ можливість здійснення короткотермінової модернізації головних частин енергоустаткування без суттєвих капіталовкладень, без особливих узгоджень та досягненням тих самих енерго-екологічних показників експлуатації, що й у першому шляху.

Враховуючи дефіцит та обмеження у розмірах та доступності фінансових ресурсів для промислових підприємств майже для усіх галузей економіки країни найбільш реалістичним та перспективним виступає другий шлях покращення енерго-екологічних показників експлуатації енергогенеруючого обладнання із застосуванням органічних видів палива.

3 цією метою підприємствам пропонується проводити модернізацію енергетичного устаткування 3 використанням сучасної високоефективної мікрофакельної технології спалювання газоподібного палива любого походження.

(C) Г.Б. Варламов, К.О. Романова, М.С. Мухін, 2019 


\section{Властивості МТС-технології, її універсальність та уніфікованість}

Для парових, водогрійних котлів чи газотурбінних, газопарових або газокомпресорних установок, що працюють на природному газі, необхідним є дотримання комплексу вимог до пальникових систем, а саме: надійність у роботі, стійкість запалювання і стабілізація фронту горіння в широких межах, забезпечення сумішоутворення заданої інтенсивності, висока енерго-екологічна ефективність, ремонтопридатність та здатність працювати у різних режимах навантаження із забезпеченням надійності та високоякісних показників енергетичної ефективності та екологічної безпеки [4]. Не усі існуючі штатні пальники, що встановлені заводами-виробниками енергетичного обладнання на відповідні установки, відповідають усім цим вимогам у повному обсязі. Це створює проблеми під час їх експлуатації, збільшує питомі витрати палива й погіршує екологічні показники їх експлуатації.

Науковцями НТУУ «КПІ ім. Ігоря Сікорського» була розроблена та впроваджена на енергетичних установках мікрофакельна технологія спалювання (МТС-технологія) різних видів газоподібного палива, таких як природний газ, газ-метан, коксовий, доменний газ, СНГ (супутній нафтовий газ), біогаз, водень і т.п. [5-7]. Використання аеродинамічних ефектів насадки Борда та умов компоновки їх у спалювальну систему для пальникових пристроїв дозволило отримати певні особливості, які позитивно впливають як на аеродинамічні, так і на спалювальні особливості пальників на їх основі [8].

Вибір насадки Борда, як базового елемента нової технології організації спалювання вуглеводневих газоподібних палив, обумовлений тим, що гідравлічні і аеродинамічні характеристики такого елемента сприяють реалізації «канонічних» принципів мінімізації токсичності пальників за рахунок одночасної реалізації попереднього сумішоутворення, стадійності горіння, прямоточної аеродинамічної схеми руху суміші. Інтенсифікація процесу сумішоутворення і стабілізація процесу горіння відбувається за рахунок існування кільцевої циркуляційної течії (вихору-стабілізатора), яка виникає у насадці Борда у (зоні вторинних течій на рис. 1).

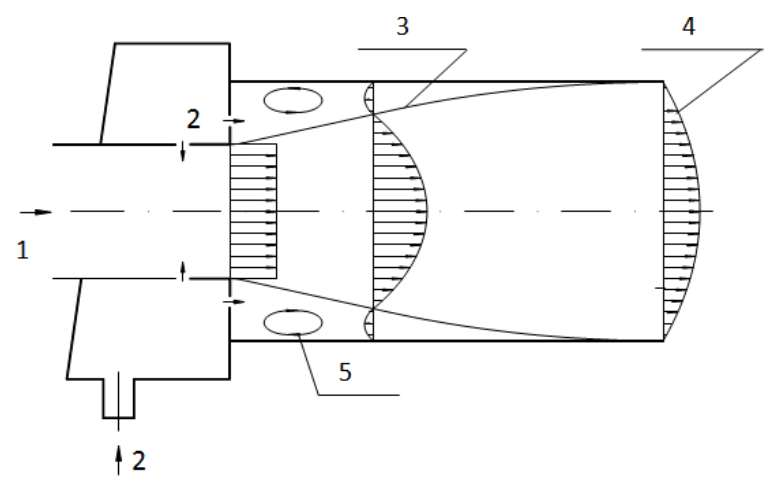

1 - окислювач; 2 - паливо; 3 - лінія нульових швидкостей;

4 - епюра швидкості; 5 - вихор-стабілізатор.

Рисунок 1 - Схема трубчастого модуля на базі насадки Борда

Однією з особливих властивостей спалювальних факельних систем на базі мікрофакельної технології $є$ їх конструктивна та технологічна простота в поєднанні з можливістю застосування різних методів сумішоутворення в тому числі: дифузійного, попереднього та комбінованого.

При дифузійному змішуванні палива й повітря з використанням трубчастих модулів із подачею палива на дифузійне сумішоутворення (елементи ТМД) спалювання суміші може відбуватися як по класичній схемі коаксіальних струменів (центральний повітряний - периферійний (кільцевий) газовий), так і по методу дотичних струменів.

Важливе значення мають особливості граничних характеристик спалювання палива (рис. 2). За підсумками комплексних експериментальних досліджень трубчастих модулів різного типу встановлено наявність:

- високої турбулентності основного потоку і додаткової локальної турбулізації при подачі палива через отвори в трубній дошці;

- вторинних течій (у вигляді тороідальних вихорів) і високі стабілізаційні властивості спалювання газоподібного палива;

- внутрішньої рециркуляції за рахунок ежекції суміші у зону спалювання.

Ці особливості знижують емісію оксидів азоту $[9,10]$, сприяють збільшенню товщини пограничного шару й інтенсифікації тепломасообмінних процесів на початковій ділянці повітряного струменя, дозволяють стабілізувати сумішоутворення й спалювання палива. Дані характеристики мають звичний для теорії та практики згорання вуглеводневих палив вигляд. Самий вузький діапазон стійкої роботи зафіксовано при попередньому сумішоутворенні (рис. 2, а). Області стабільного займання для трубчастих модулів типу ТМД та ТМДН (дифузійне із внутрішньою насадкою) практично співпадають. Модуль ТМД 
має стійкий діапазон горіння у «бідній» на паливо області (рис. 2, в). При зміні конструктивних особливостей трубчастого модуля змінюється не тільки структура, але і далекобійність факела.
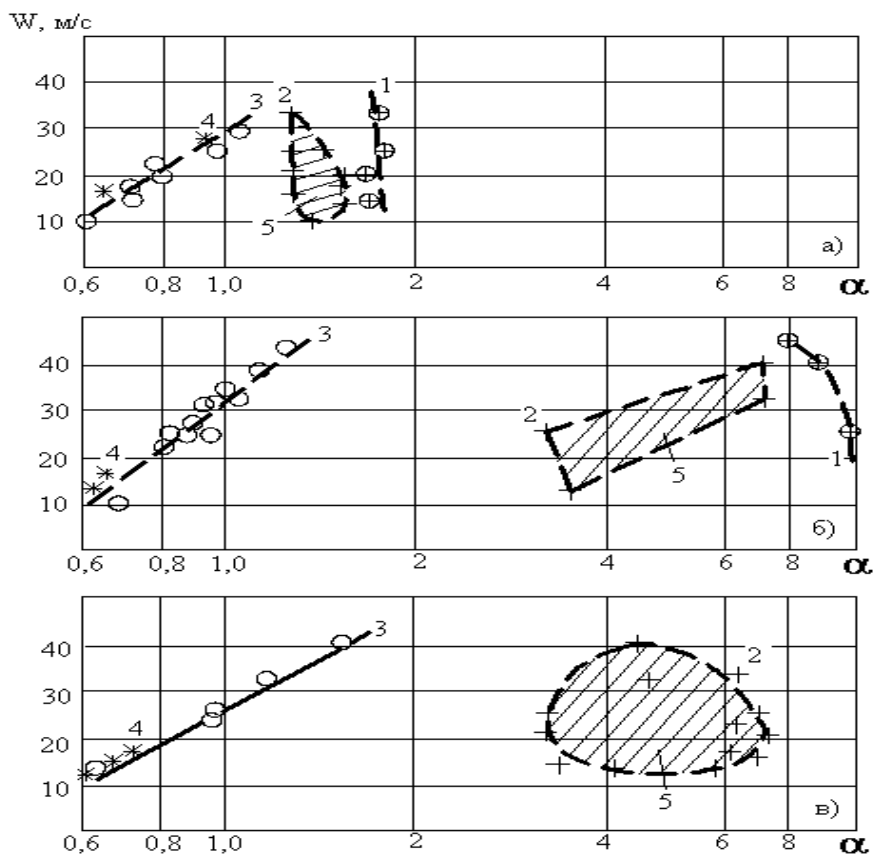

а) - трубчастий модуль ТМП (попереднє сумішоутворення без внутрішньої насадки); б) - трубчастий модуль ТМДН (дифузійне сумішоутворення із внутрішньою насадкою);

в) - трубчастий модуль ТМД (дифузійне сумішоутворення без внутрішньої насадки): 1 - межа «бідного» на паливо зриву полум я; 2 - межа електроіскрового займання суміші; 3 - режими стійкого горіння суміші; 4 - режими «багатого» на паливо зриву полум я; 5 - зона стабільного займання суміші. Рисунок 2 - Граничні характеристики горіння природного газу при різних умовах сумішоутворення

Далекобійність факела (L) у модулі без насадки (рис. 3) є найменша. Це обумовлено відзначеною вище аерацією кореня факела, при цьому факел має найбільший відрив від гирла струменя. Збільшення далекобійності факелів у модулях з насадками обумовлено не тільки зниженням аерації кореня факела, але і «ламінаризацією» початкової ділянки факела у результаті підвищення його температури. При використанні системи трубчастих модулів у пальниковому пристрої виникають додаткові особливості розвитку факелів. При багатомодульному виконанні пальників відсутня необхідність в установці на кожному модулі зовнішньої насадки, тому що в цьому випадку існує природна зона розділу між сусідніми модулями, яка виконує усі позитивні функції зовнішньої насадки.

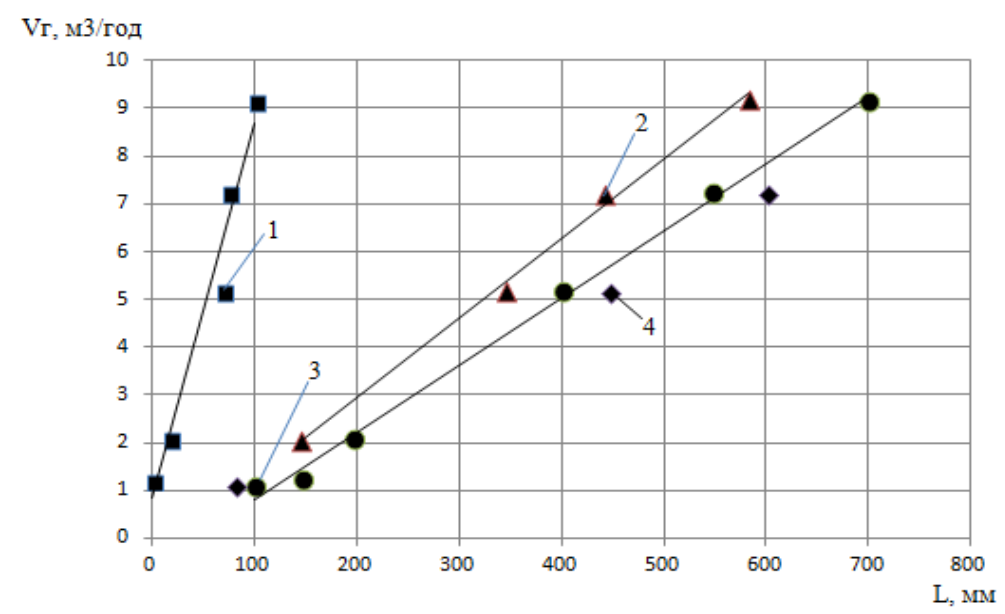

( L - далекобійність факелу, Vг - витрата природного газу): 1- модуль без насадки;

2- модуль без насадки у складі багатомодульного пальника;

3-модуль із зовнішньою насадкою; 4 - модуль із внутрішньою насадкою [9]

Рисунок 3 - Аеродинамічні характеристики факелів на базі трубчастих модулів

Дослідження аеродинамічних характеристик штатної камери згорання 
Для перевірки можливості заміни штатних пальників на нові пальники мікрофакельного типу, що розроблені науковцями НТУУ «КПІ ім. Ігоря Сікорського», було обрано камеру згорання газотурбінної установки у складі газоперекачувального агрегату (ГПА) типу ГТК-10 (потужність 10 МВТ) (рис.4).

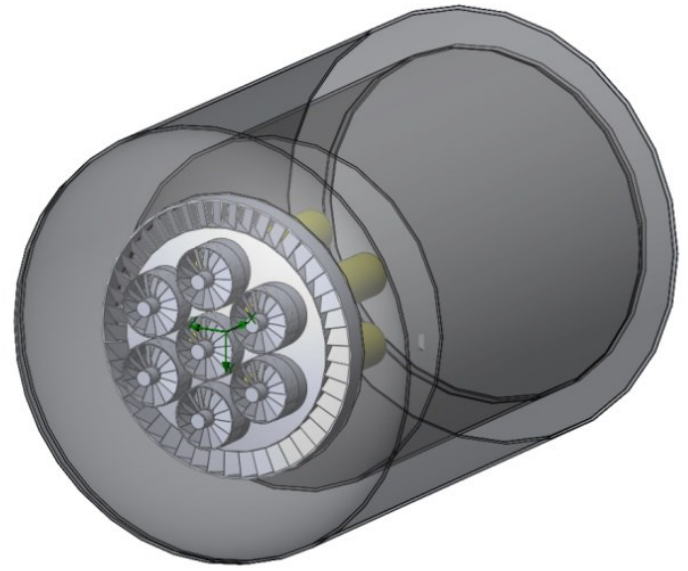

a)
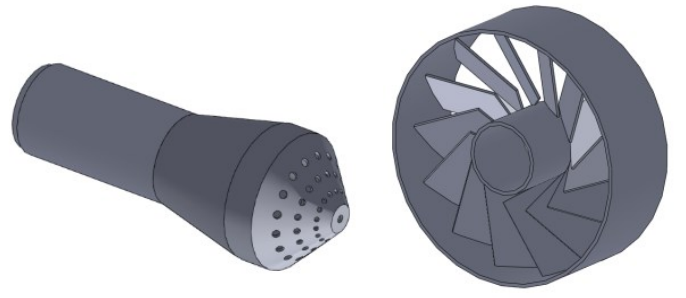

б)

а) штатна (заводська) камера згорання з пальниками й периферійним повітряним регістром;

б) форсунка та повітряний регістр пальника

Рисунок 4 - 3-Д моделі

Вибір даного типу ГПА є не випадковим, оскільки такі агрегати встановлені на газотранспортних магістральних газопроводах України, Росії, Казахстану, Туркменістану, Азербайджану та Ірану у загальній кількості понад 1500 одиниць. Аналогічну конструкцію камери згоряння мають ГПА типу ГТ-750-6 потужністю 6 МВт, яких налічується близько 750 одиниць у тих самих країнах.

Для дослідження і аналізу аеродинамічних та теплових процесів у штатній камері згорання розроблено математичну модель камери згорання у програмному середовищі SolidWorks.

Граничними умовами у моделі є геометричні межі модельованої області розрахунку та наступні реальні параметри установки: на вхід камери згорання повітря подається масовою витратою 85,25 кг/с, температурою $400^{\circ} \mathrm{C}$, тиском на вході - 103325 Па і на виході - 101325 Па; на вході у газову форсунку подача палива становить $1 \mathrm{~m}^{3} / \mathrm{c} 3$ температурою $150^{\circ} \mathrm{C}$; матеріал жарової труби - жаростійка аустенітна сталь марки ХН60ВТ.

Подача палива у штатній (заводській) камері згорання відбувається через сім регістрових (лопаткових) пальників, у які подається також біля 65\% первинного повітря. Залишок повітря (близько $35 \%$ подається у камеру згорання через основний периферійний повітряний регістр для охолодження стінок жарової труби у вигляді завихреного пристінного пограничного шару. Для зменшення похибки розрахунку у середині жарової труби задано розрахункову сітку з меншим кроком. Для моделювання процесу горіння та врахування усіх хімічних реакцій, що проходять в камері згоряння, було змодельовано факели, що передають необхідний тепловий потік і є прозорими для газового потоку. Модель складають рівняння променевого теплового потоку, залежності для визначення півсферичної інтегральної міри чорноти продуктів згорання, ефективна довжина шляху променя, коефіцієнт ослаблення випромінювання.

Модель дозволила задати реальні параметри повітряних потоків, температурних полів у камері згорання, дослідити головні особливості течій і теплообміну у потоках на вході у фронтовий пристрій, у середині об`єму жарової труби та на виході з неї перед потраплянням гарячих газів на лопатки газової турбіни. Під час моделювання були обрані характерні площини перерізу камери згорання (рис. 5) 3 можливістю спостереження та аналізу параметрів потоків як навколо, так і в середині жарової труби. Адекватність моделі перевірялася співставленням величин параметрів в моделі та на реальній установці під час експлуатаційних випробувань та за існуючими опублікованими даними $[11,12]$.

Проведені дослідження на моделі дозволили визначити головні особливості протікання аеродинамічних процесів руху повітряних потоків у жаровій трубі та пальниках фронтового пристрою камери згорання. 

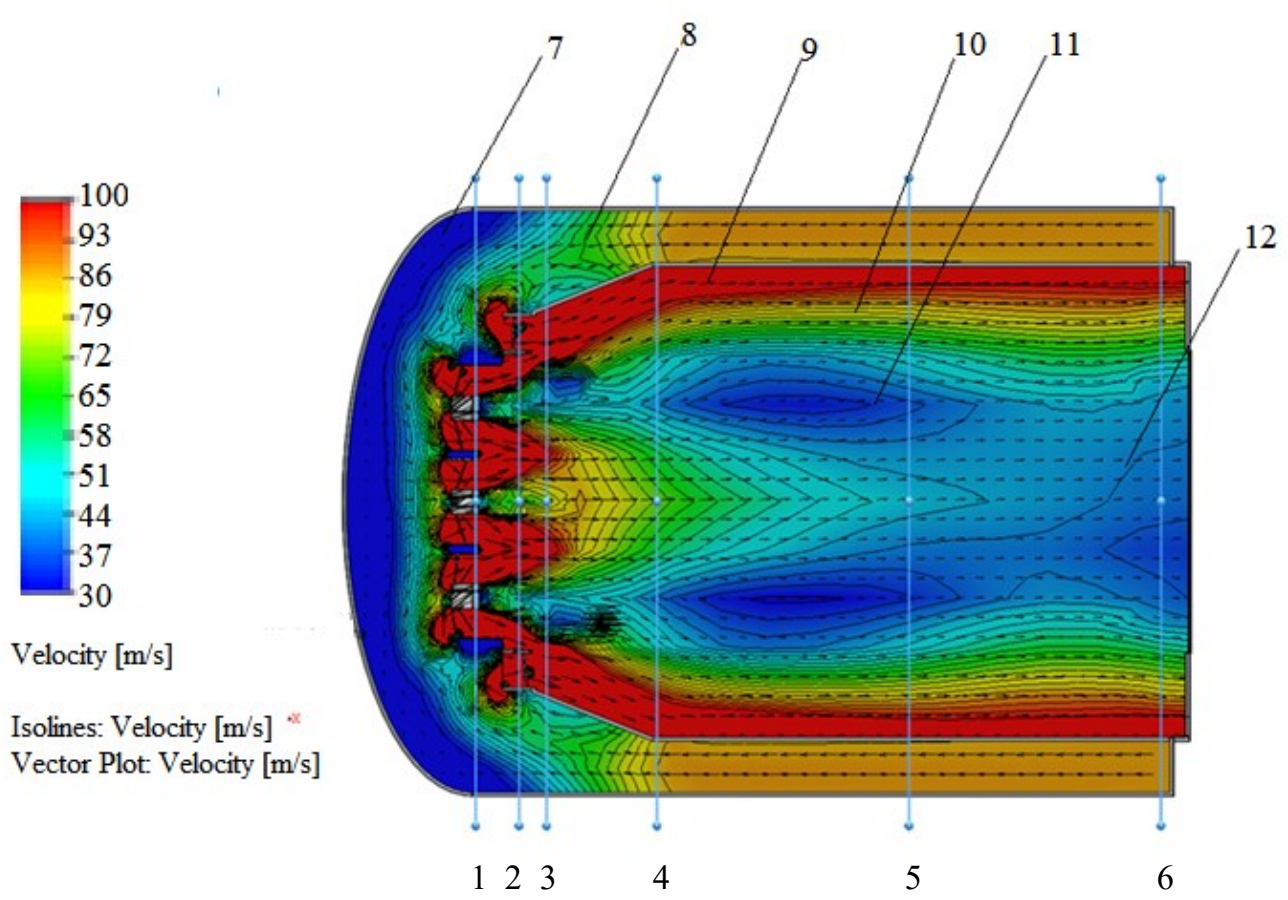

Velocity $[\mathrm{m} / \mathrm{s}]$

Isolines: Velocity $[\mathrm{m} / \mathrm{s}] *$

Vector Plot: Velocity $[\mathrm{m} / \mathrm{s}]$

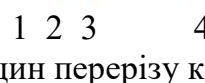

5

1-6 - позначення поперечних площин перерізу камери згорання, 7-12 - локальні значення швидкості повітря $(7-30 \mathrm{~m} / \mathrm{c}, 8-60 \mathrm{~m} / \mathrm{c}, 9-100 \mathrm{~m} / \mathrm{c}, 10-75 \mathrm{~m} / \mathrm{c}, 11-40 \mathrm{M} / \mathrm{c}, 12-45 \mathrm{~m} / \mathrm{c})$

Рисунок 5 - Розподіл швидкості повітря на повздовжніх площинах перерізу камери згорання ГТУ зі штатними пальниками

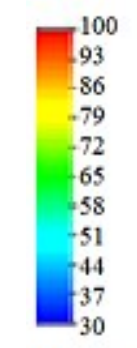

Velocity $[\mathrm{m} / \mathrm{s}]$

Isolines: Velocity $[\mathrm{m} / \mathrm{s}]]^{*}$ Vector Plot Velocky [m's]

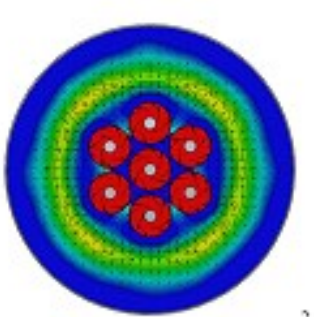

2

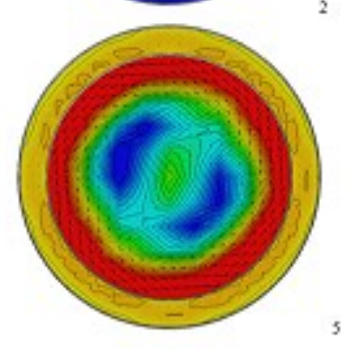

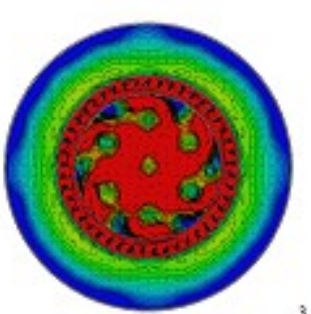

3
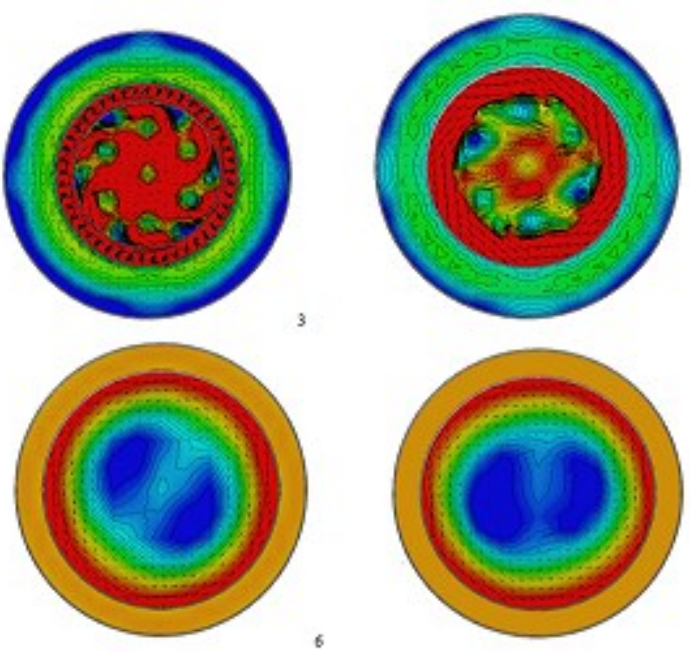

Рисунок 6 - Розподіл швидкості повітря на шістьох площинах перерізу камери згорання ГТУ зі штатними пальниками

Отримані результати свідчать про значну нерівномірність полів швидкостей повітря у фронтальному та повздовжньому (вздовж вісі) перерізах камери згорання. Найбільшу швидкість має повітря, що рухається в пристінному шарі жарової труби. Швидкість від пристінної області до центральної вісі значно знижується. Наприклад, в поперечній площині перерізу 5 швидкість в центрі камери згорання складає $40 \mathrm{~m} / \mathrm{c}$, на периферії іiі значення складає $95 \mathrm{~m} / \mathrm{c}$. А в поперечній площині перерізу 6 швидкість в центрі - 35 м/с, на периферії - 100 м/с. Дана нерівномірність зберігається по поперечному перерізу і вздовж вісі. Значна нерівномірність швидкостей призводить до постійних змін тиску в різних зонах по всьому об’єму жарової труби та наявності різнонаправлених пульсацій потоку, які на виході камери згорання при попаданні на лопатки турбіни сприяють виникненню вібрації не тільки турбіни, а і всієї ГТУ.

Аналізуючи результати досліджень теплових процесів в камері спалювання зі штатними пальниками, що отримані за допомогою комп’ютерного моделювання камери згорання газотурбінної 
установки в складі ГПА типу ГТК-10 зі штатною пальниковою системою (рис. 7), можна зробити висновок, що поле температур характеризується також значною нерівномірністю, що є причиною виникнення термічних напруг, що негативно впливає на ресурс та ефективність роботи ГТУ. Окрім цього, в ядрі факела потік має високу температуру та низьку відносну швидкість, що створює умови для інтенсифікації процесу виникнення NOx.

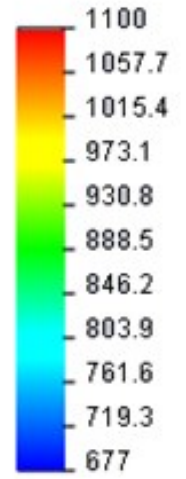

Temperature $[\mathrm{K}]$

Isolines: Temperature $[\mathrm{K}]$ Vector Plot: Velocity $[\mathrm{m} / \mathrm{s}]$

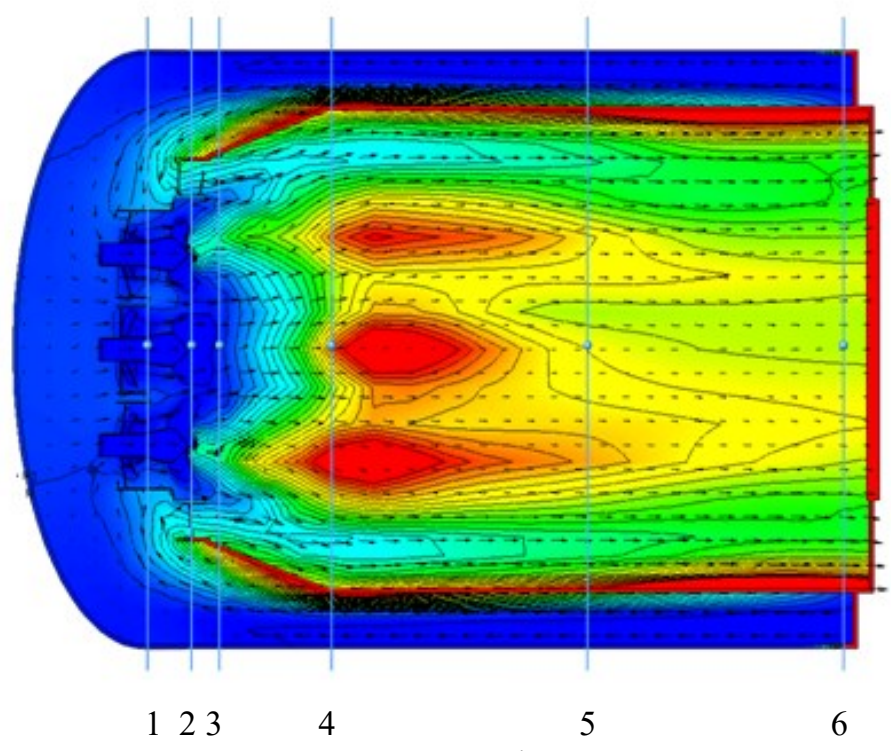

1-6 - позначення поперечних площин перерізу

Рисунок 7 - Розподіл температур на повздовжній площині перерізу камери згорання ГТУ зі штатним пальником

В камері згорання $з$ пальниковою системою на базі мікрофакельної технології (рис. 8) відсутні області різкої зміни швидкості потоку та нерівномірності швидкостей за напрямком руху газів від фронтальної частини до виходу із жарової труби, що досягається упорядкованою структурою та оптимізованим розташуванням трубчастих модулів по всьому поперечному перерізу жарової труби (рис. 9,10). Поле швидкостей характеризується значною рівномірністю.
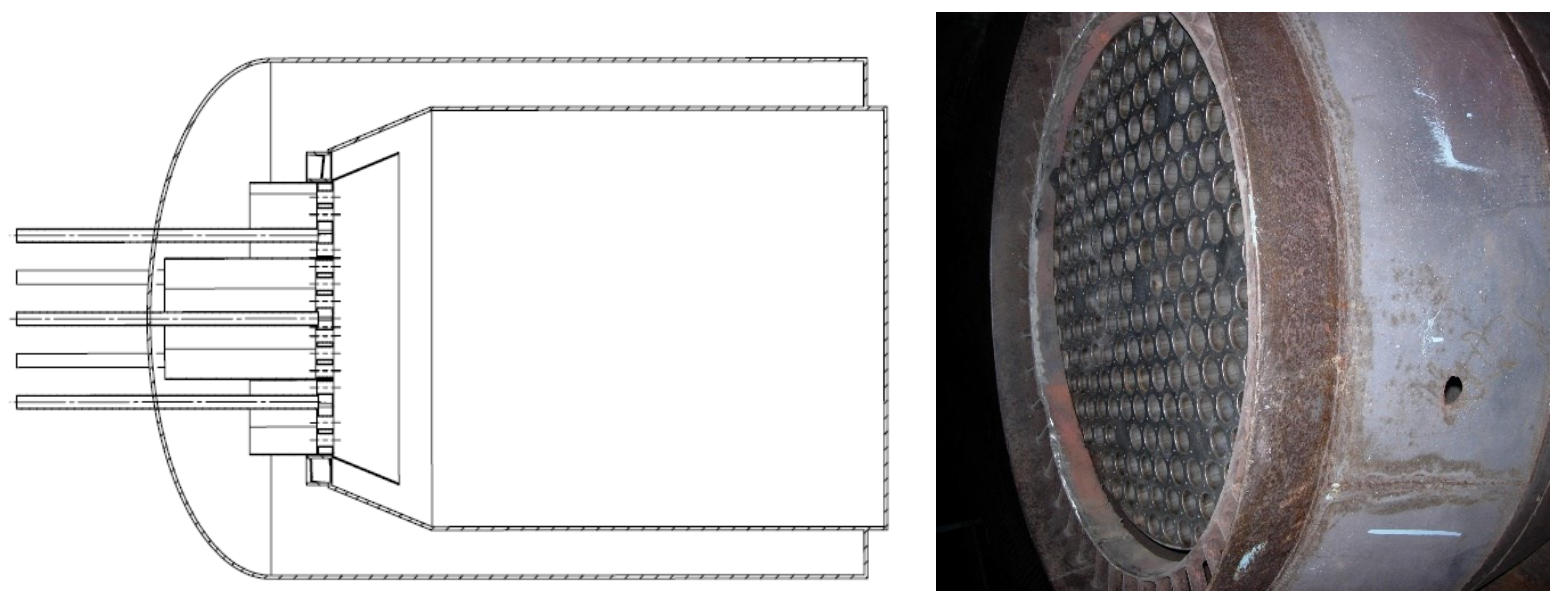

а) креслення (збірка), б) фото фронтового пристрою із МТС-пальником Рисунок 8 - Загальний вигляд камери згорання ГТУ у складі ГПА типу ГТК-10 


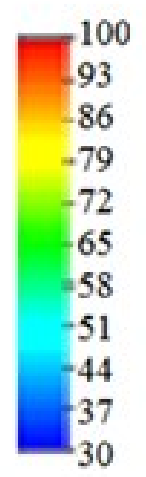

Velocity $[\mathrm{m} / \mathrm{s}]$

Isolines: Velocity $[\mathrm{m} / \mathrm{s}]$ *

Vector Plot Velocity $[\mathrm{m} / \mathrm{s}]$

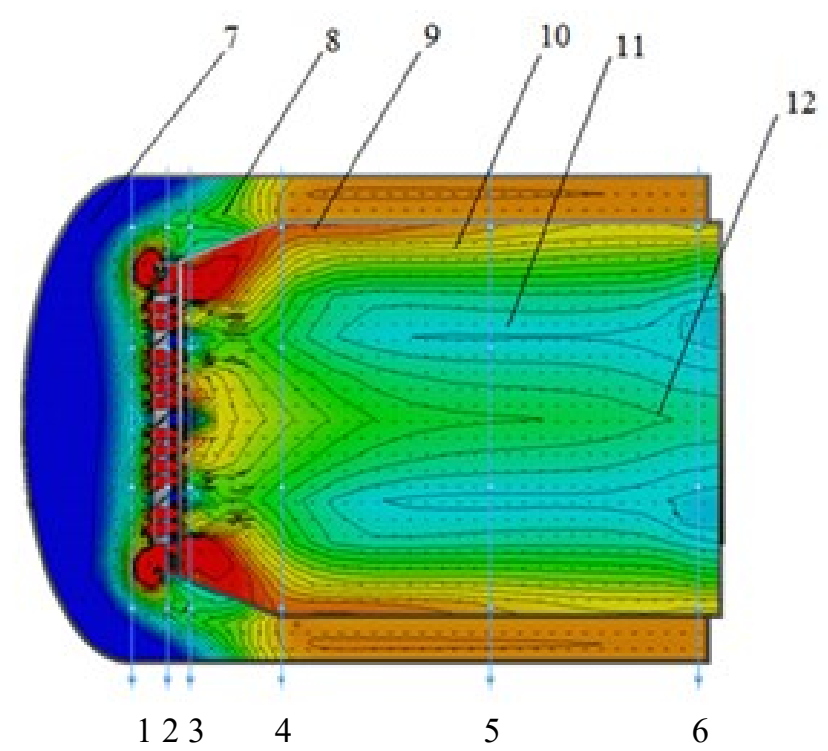

1-6 - позначення поперечних площинах перерізу, 7-12 - локальні значення $(7-30 \mathrm{~m} / \mathrm{c}, 8-65 \mathrm{~m} / \mathrm{c}, 9-85 \mathrm{~m} / \mathrm{c}, 10-75 \mathrm{~m} / \mathrm{c}, 11-55 \mathrm{~m} / \mathrm{c}, 12-50 \mathrm{~m} / \mathrm{c})$

Рисунок 9 - Розподіл швидкості повітря на повздовжній площині перерізу камери згорання ГТУ 3 MTC-пальником $з$ дифузійною подачею палива

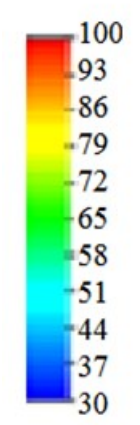

Velocity [m/s]

Isolines: Velocity $[\mathrm{m} / \mathrm{s}]$ * Vector Plot: Velocity $[\mathrm{m} / \mathrm{s}]$
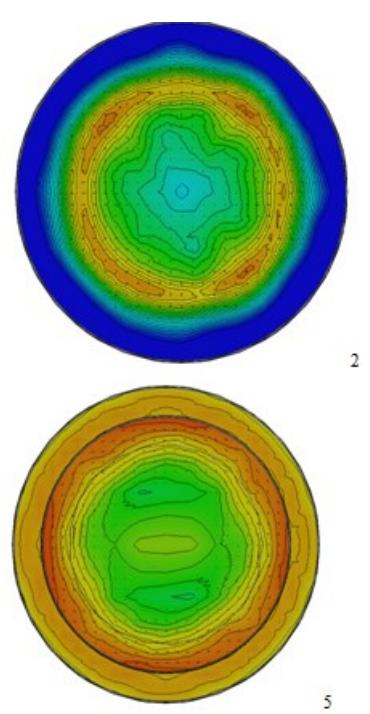

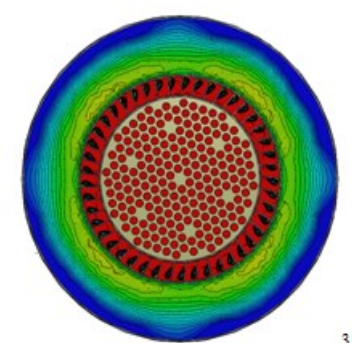

3
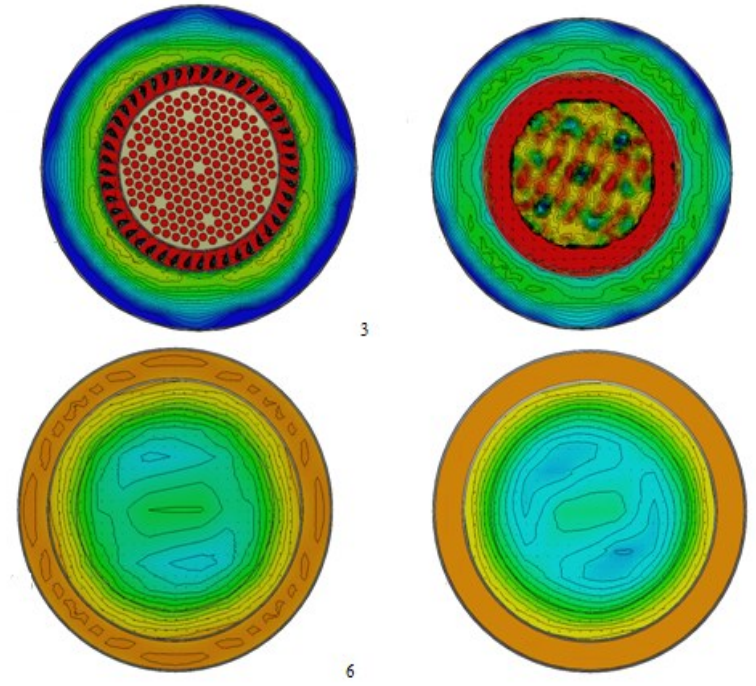

Рисунок 10 - Розподіл швидкості повітря на шістьох площинах перерізу камери згорання ГТУ 3

МТС-пальником з дифузійною подачею палива

Поле швидкості стало на 25\% більш рівномірним по довжині камери і на $40 \%$ по поперечних площинах перерізу (рис. 9).

Порівняння результатів, що отримані за допомогою комп'ютерного моделювання камери згорання газотурбінної установки в складі ГПА типу ГТК-10 зі штатними пальниками (рис. 7) та МТС-пальником (рис. 11) відповідно, дозволило зробити висновок, що пальникова система на базі мікрофакельної технології має певні переваги. Ці переваги торкаються розподілу температур, а саме: поле температур в жаровій трубі має високу рівномірність у площинах перерізу та по довжині жарової труби. Поле температур стало на 30\% більш рівномірним по довжині камери і на 50\% по поперечних перерізах порівняно зі штатним пальником. Крім того, у ядрі факелу температура має значно менше значення, що сприяє у процесі спалювання зменшенню емісії термічних оксидів азоту $\mathrm{NO}_{\mathrm{x}}$. 

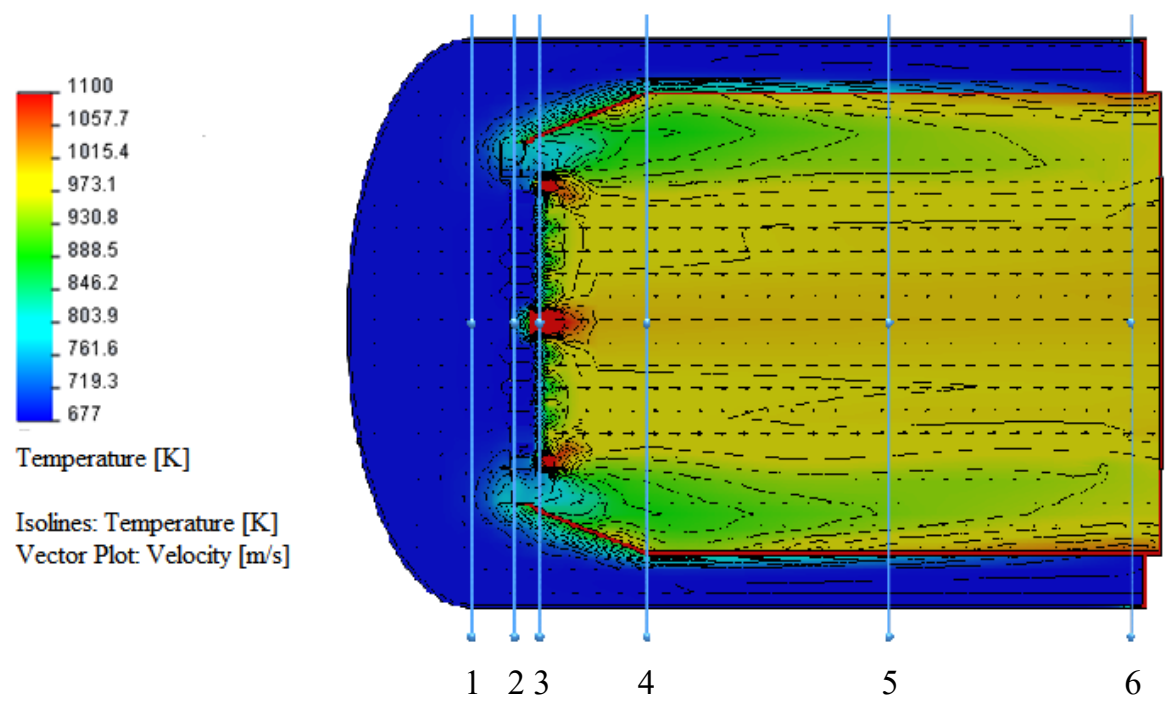

1-6 - позначення поперечних площин перерізу

Рисунок 11 - Розподіл температур на повздовжній площині перерізу камери згорання ГТУ з МТСпальником

Одночасно з цим, пальникова система на базі МТС-технології за рахунок більш низького аеродинамічного опору дозволяе збільшити на $15 \ldots 20 \%$ масову частку повітря, що бере участь безпосередньо в процесі спалювання. Це сприяє збільшенню швидкості руху повітряного потоку в зоні горіння й зменшує термін перебування суміші у зоні спалювання, що також дозволяє зменшити емісію викидів $\mathrm{NO}_{x}$ та СO.

\section{Висновки}

Отримані результати досліджень аеродинамічних і теплових особливостей роботи камери згорання 3 пальниковою системою на базі мікрофакельної технології спалювання свідчать про наявність комплексу позитивних ефектів:

- більш високий рівень рівномірності полів швидкостей та температур (поле швидкості стало на 25\% більш рівномірним по довжині камери і на 40\% по поперечних перерізах, а поле температур відповідно на $30 \%$ та 50\%);

- підвищення екологічності спалювання газоподібного палива за рахунок прямоточності руху газоповітряної суміші, комбінованого сумішоутворення (попереднього і дифузійного), стадійності i мікрофакельності спалювання, високої турбулізації і наявності внутрішньої рециркуляції потоку,

- у ядрі факелу температура має значно менше значення, внаслідок чого у процесі спалювання відбувається зменшення емісії термічних оксидів азоту $\mathrm{NO}_{x}$;

- можливість здійснювати короткострокову (протягом 8 робочих годин без зміни конструкції жарової труби та фронтового пристрою) заміну штатного пальника на МТС-пальник безпосередньо на установці;

- здатність працювати у широкому діапазоні навантаження із забезпеченням надійності та високоякісних показників енергетичної ефективності та екологічної безпеки;

- простота з можливістю застосування різних методів сумішоутворення в тому числі: дифузійного, попереднього та комбінованого під час експлуатації та зміни режимів навантаження установки.

Перераховані вище позитивні ефекти МТС-технології та пальників на їі основі дозволяють підвищити рівень ефективності та екологічної безпеки експлуатації газотурбінних установок та інших типів енергетичних установок [13-18].

\section{Список використаної літератури}

1. Директива Свропарламенту та Ради СC 2001/80/EC «Про комплексне запобігання i контроль забруднень». Законодавство Украӥни: веб-сайт. URL: https://zakon.rada.gov.ua/laws/show/994_913 (дата звернення: 08.05.2019).

2. Директива Європарламенту та Ради ЄС 2010/75/ЄС «Про промислові викиди». Міністерство Юстииї̈: веб-сайт. URL: https://old.minjust.gov.ua/file/33301.docx (дата звернення: 08.05.2019).

3. Про Основні засади (стратегію) державної екологічної політики України на період до 2030 року: Закон України від 28 лют. 2019 р. № 2697-VIII. URL: https://zakon.rada.gov.ua/laws/show/2697-19\#n14 (дата звернення: 10.05.2019). 
4. Халатов А.А. Парогазові установки в електроенергетиці: сучасний стан і перспективи розвитку в Україні. Научные и прикладные вопросы промышленного газотурбостроения. $2014 . \quad$ т. 1. C. $41-52$.

5. Газовий пальник: пат. 50168 Україна: МПК F23D14/02, F23D14/22. № 2001 117468; заявл. 01.11.2001; опубл. 15.10.2002, Бюл. № 10.

6. Газовий пальник: пат. 56602А Україна: МПК F23D14/02, F23D14/22. № 2002 076319; заявл. 29.07.2002; опубл. 15.05.2003, Бюл. № 5.

7. Низькоемісійний газовий пальник трубчастого типу з направленим повітряним потоком: пат. 98095 Україна: МПК F23D14/02, F23D14/22. № a 2011 13153; заявл. 08.11.2011; опубл. 10.04.2012, Бюл. № 7 .

8. Любчик Г.М., Марченко Г.С., Варламов Г.Б., Мікулін Г.О., Макаренко В.В., Левчук С.О. Емісійні характеристики пальників на базі трубчастих модулів. Экотехнологии и ресурсосбережение. 2004. №1. C. 73-79.

9. Любчик Г.Н., Левчук С.А., Варламов Г.Б., Марченко Г.С., Микулин Г.А. Особенности эмиссии NOx и CO в горелках на базе трубчатых модулей. Енергетика: економіка, технологї̈, екологія. 2001. № 4. C. 59-63.

10. Любчик Г.Н., Варламов Г.Б. Новая технология создания и использования эффективных и высокоэкологичных горелочных устройств для энергетических котлов и камер сгорания ГТУ и ПГУ. Инновационное развитие топливно-энергетического комплекса: проблемы и возможности. Киев, 2004. С $.115-121$.

11. Сударев А.В., Антоновский В.И. «Камеры сгорания газотурбинных установок: Теплообмен.» Л.: Машиностроение, 1985. - 272 с.

12. Сторожук Я.П. Камеры сгорания стационарных газотурбинных и парогазовых установок: Машиностроение, Ленингр. Отделение, 1978.- 231 с.

13. Варламов Г.Б., Халатов А.А., Позняков П.О., Юрашев Д.Н. Нове покоління пальникових систем ГТУ на основі трубчатої технології спалювання газу. Східно-європейський журнал передових технологій. 2012. №10. С. 9-14.

14. Говдяк Р.М., Шелковский Б.И., Чабанович Л.Б., Гриник О.Г., Любчик Г.Н., Варламов Г.Б. Перспективы повышения надежности, экологической безопасности и энергетической эффективности ГПА на основе применения трубчатой технологи сжигания газа. Праці Iнституту електродинаміки Національної академії наук України. Спеціальний випуск. Київ. 2006. С. 54-57.

15. Варламов Г.Б., Любчик Г.Н., Олиневич И.В., Ивасенко А.В. Технология повышения энергетической и экологической эффективности работы котлов и камер сгорания ГТУ. Мир техники и технологий. 2006. №4. С. 64-65. $435 \mathrm{c}$.

16. Христич В.А., Варламов Г.Б. Газотурбинные установки: история и перспективы. Киев. 2006.

17. Любчик Г.Н., Варламов Г.Б., Романов В.В., Ванцовский В.Г., Вилкул В.В. Результаты испытаний камеры сгорания ГТД ДГ 80 с низко-эмиссионным горелочным устройством на базе трубчатых модулей. Восточно-Европейский журнал передовых технологий. 2009. № 6. С. 13-18.

18. Варламов Г.Б., Марчук Я.С., Беккер М.В., Любчик Г.М. , Камаєв Ю.М., Позняков П.О., Кузьменко Д.О. Трубчаста технологія газоспалювання - прорив у енергозбереженні та екологічності транспортування природного газу. Нафтова і газова енергетика. 2010. №1. С. 60-63.

G. Varlamov, Dr. Sc. Sciences., Prof., ORCID 0000-0002-4818-2603

K. Romanova, Cand. Sc. (Eng.), Assis. Prof., ORCID 0000-0001-9738-3383

M. Mukhin, Master, ORCID 0000-0002-8961-6543

National Technical University of Ukraine «Igor Sikorsky Kyiv Polytechnic Institute» GAS TURBINE RECEPTION CAMERA AERODYNAMIC AND THERMAL USING ADVANTAGES
BY MICROFACCIOLOGY OF GAS DISCHARGE

Надійшла 12.02.2019

Received 12.02.2019 